\title{
Resurrection Appearances of Jesus as After-Death Communication: Response to Ken Vincent
}

\author{
Gary R. Habermas, Ph.D. \\ Liberty University
}

\begin{abstract}
Jesus' resurrection appearances would in some sense comprise after-death messages. But this designation does not necessarily identify them as the sort of after-death communications (ADCs) that are well-known to readers of this Journal. More generally, to hold that the resurrection appearances were ADCs, at least as Ken Vincent has argued, seems to commit a logical fallacy, so that the form of the argument itself cannot sustain the weight of the conclusion. The most that the argument can indicate is that there are some similarities, not that they are necessarily the same class of events. More specifically, there are at least six crucial considerations that dispute Jesus' resurrection appearances being ADCs in the usual sense of these events.
\end{abstract}

KEY WORDS: after death communication (ADC), informal logical fallacy, Jesus, resurrection

For more than a century, researchers have examined extensively various sorts of phenomena usually termed after-death communications (ADCs). The species of ADCs most relevant to this article involves reports that previously deceased persons were seen in some form by others, occasionally in evidential ways that seem to argue in favor of the dead individual's actual presence. Though with different emphases, many scholars have suggested that Jesus' post-resurrection appearances may be best interpreted as a variation of such occurrences;

Gary R. Habermas, Ph.D., is Distinguished Research Professor and Chair of the Philosophy Department at Liberty University. He has published some 37 books, plus over 60 chapters or articles in other books, often on the subject of the resurrection of Jesus Christ. Correspondence regarding this article may be addressed to Dr. Habermas at email: ghabermas@liberty.edu. 
major works include those of Michael Perry (1959, pp. 157-173), Theodor Keim (1872, pp. 602-605), and Dale Allison (2005, pp. 269-299).

In this article, I will argue that although at least Jesus' wellevidenced post-resurrection appearances would in some sense (by definition) involve communications after his death, it does not follow necessarily that these events were therefore the same, or even very similar, to various sorts of ADCs commonly found in the literature. I find many forceful reasons to think that Jesus' appearances were quite different from these regular ADCs.

To place my comments here in perspective, I was invited to write this response by Jan Holden, the Editor of this Journal, which I appreciated. The study of Jesus' resurrection in light of the state of contemporary focused research-whether atheist, agnostic, liberal, or conservative-has been my chief area of specialization for about 40 years. It is against this background of some 18 books and dozens of articles (Habermas, 2003, 2005, 2006) that I make the comments herein. In the process of writing, I was also able to have a lengthy and delightful conversation with Ken Vincent, a discussion that I enjoyed thoroughly (personal communication, July 16, 2012). My appreciation for him remains unaffected by our differences.

\section{A Recent Example}

For Vincent (2012), Jesus actually rose from the dead but in a more spiritual, non-bodily manner. He holds this position chiefly for two reasons: This view is "more consistent with the New Testament accounts," and "it is most compatible with scientific research" over more than a century (p. 137).

Regarding the initial point, following contemporary scholarship, Paul is the only eyewitness reporter of a resurrection appearance that exists, and he also is the author who presents the only "verified secondhand reports of the resurrection" (Vincent, 2012, p. 138) from his interviews with two additional witnesses, Peter and James, the brother of Jesus. Based on such insider information, Paul reported less than bodily resurrection appearances: "Paul knew nothing about a physical resurrection of Jesus" (p. 138). Whereas it is true that the Gospel writers "implied a physical resurrection of Jesus because of the empty tomb" (p. 138) along with other details, theirs are not the earliest accounts but were written a fair amount of time later (pp. 138-140).

Regarding Vincent's second reason, he asserted that with "Paul's view-which is the modern view-that Jesus' resurrection was an 
ADC" the advantage is that "spiritual beings can appear at will from the afterlife" (p. 140). The "problem exists only for those advocating a "physical body' scenario" pertaining to the resurrection (p. 140). Then Vincent presented nine characteristics of Jesus' resurrection appearances and compared them to contemporary ADC accounts, indicating many similarities (pp. 140-145). He also argued for verified ADC accounts, particularly in cases where more than one person witnesses them, when previously-unknown information is imparted, and especially when lives are changed (p. 145).

Vincent's interest in this area sheds some light on the personal comfort that it affords him, as the last sentence on page 147 indicates clearly. In my view, he has done some relevant thinking and study on related issues, presenting a thoughtful interaction with the subject matter. The essay is also written fairly, and he took care to mention other possible positions besides its own. Further, I found his tone to be comforting, non-polemical, and even pastoral.

Further, his examples and comparisons to related phenomena such as ADC encounters provide some background. He included a thoughtful discussion of how to assess the veridical nature of ADC accounts. Overall, I think he is correct regarding ADC accounts that are witnessed by multiple persons and that provide verifiable and previously unknown information. Although changed lives are helpful, I do not weigh them the same way he does, but this is a minor point. Elsewhere, Vincent (2009) referred to at least some of these ADC accounts as "post death visions," a description I also find helpful.

Perhaps most crucially, although Vincent and I differ substantially regarding the manner or form of Jesus' appearances after his death, we nevertheless share in common the positions that Jesus was really raised from the dead, that he is actually alive today, and that at least what might be called the general afterlife thesis is well-evidenced by the data. Therefore, it should be noted carefully that our differences are chiefly in regard to the form and meaning of Jesus' resurrection appearances, rather than the reality of the event, per se. Thus, the fact that Jesus was truly raised from the dead is a vital and even central area of agreement between us.

\section{General Evaluation of Vincent's Thesis}

Vincent frequently cited particular scholarly views that support his interpretations of Jesus' resurrection appearances, which I found helpful. But he spoke of these as the accepted scholarly positions. However, 
several of these stances that he identified are not those of the majority of the historians, philosophers, and New Testament researchers who study this topic (Habermas, 2005). For example, in providing a large amount of his background work for several crucial issues, Vincent depended chiefly on the conclusions of a single research text by L. Michael White (2004). But White's conclusions are significantly outside the mainstream in matters such as the dating of the Gospels.

In contrast, one of the exceptionally influential authors that Vincent (2012) cited favorably, Luke Timothy Johnson (pp. 1-2), differed significantly in a number of crucial aspects. White dated the Gospels and Acts to between approximately 70 and $120 \mathrm{CE}$ (pp. 4-6), whereas Johnson (1986) dated them from about 60-95 CE (pp. 144, 198, 470). Even Bart Ehrman (2000), perhaps the best known skeptical New Testament scholar and an agnostic, dated the Gospels and Acts from approximately 65-90/95 CE (pp. 43, 122). For Johnson and Ehrman, that is a difference of about 5/10-25 years earlier per Gospel than White indicated, which is clearly a substantial gap.

This example shows precisely why more than one primary sourcebook for the New Testament conclusions is crucial, especially on muchdisputed issues in which these sorts of differences in basic research could make a huge difference in the final conclusions. After all, Vincent contrasted Paul's writings with the Gospels, so it is clearly to his advantage to use someone like White who places the latter beyond the outside range of dates that specialists generally take, as a survey would indicate. Of course it could be said that various scholars take different views, and that would be true. But my point is that Johnson and Ehrman are part of the majority position, whereas White is not. So when the latter is basically the only reference used for these conclusions, I perceive an imbalance.

In Vincent's (2012) article, he took several other positions that may have been popular a few decades ago or longer but are no longer quite so "cutting edge" today, yet he still termed these the "modern view" (p. 140). For me, a larger concern is that, a couple of times, he missed crucial distinctions between critical positions, seemingly lumping together some views that are actually quite often even opposed to each other. True, even specialists can be mistaken, but they are at least as appropriate to cite as scholars who hold a minority view. An example will be pursued in the next section below.

Another issue is the confusion on the New Testament Greek text in John 20:17 (pp. 139-140). The mix-up is understandable, but it also fa- 
vors Vincent's conclusions, although the comment is mistaken. Vincent asserted that, "Unlike the Gospel of Matthew in which Mary Magdalene touched Jesus, Jesus told Mary not to touch him" in John 20:17 (p. 139). That is how the King James Version of 1611 translated the words. But in the majority of contemporary translations, the actual Greek has Jesus telling Mary to "stop holding" or "stop clinging" to him. In other words, she apparently was not only touching him, but clutching him, as in Matthew, and Jesus simply requested to be allowed to move on and finish what he needed to accomplish!

Crucially, the most damaging general argument throughout the main portion of the essay (pp. 140-145) involves the logical structure of the argument itself. Vincent seemed to argue that various similarities between Jesus' New Testament resurrection accounts and ADC communications indicate the sameness, virtual sameness, or close relatedness of the events in question. At times, he seemed to make this implication quite strongly, typified most by the list on page 7 . Following this list, Vincent clearly asserted that "such accounts demonstrate that all of the above nine behaviors exhibited in the New Testament are present in modern-day accounts" (p. 141). However, the heart of this misconception is that similarity does not necessarily prove causality, sameness, or even formal relatedness. Two things can appear very similar and yet be totally unrelated. To say otherwise is an informal logical fallacy (Copi, 1986, especially pp. 100-101).

Unfortunately, the form of this argument appears quite commonly in modern research, invoking the crucial logical error. Whereas coherence arguments may indicate compatibility or similarity among different things, they definitely do not require causation or sameness. In other words, simply because two series of events or lines of thought are similar, even very much so, this similarity by no means proves or indicates either that they are the same or that one caused the other.

Therefore, if I am correct about this, the most prominent argument in Vincent's essay, upon which the title of the article is seemingly based, would appear not to follow. Although he may argue that particular events (i.e., the resurrection appearances of Jesus and certain contemporary ADC accounts) may even have many similarities in common, to assert that they are therefore the same class of occurrences-more specifically, that the resurrection is an example or type of ADC-appears thus to be fallacious and hence unwarranted. So it appears to me that the implied connection in the title of Vincent's article is unjustified. 


\section{Specific Evaluation of Vincent's Thesis}

There are still other ways to show that the resurrection appearances are not the same as the general ADC phenomena that Vincent cited. Very crucial differences between Jesus' resurrection appearances and ADC accounts indicate that the former are not examples of the latter. Once again, I want to be very clear that I am not arguing here about the more crucial topic regarding whether or not Jesus was actually raised from the dead and appeared afterwards in some form, for Vincent and I both agree that he did so. Rather, I am discussing whether the resurrection appearances should be understood as disembodied in nature and more as examples of the ADC phenomena in the literature, as Vincent argues. As before, our differences concern chiefly the form and meaning of these appearances.

One more crucial distinction is necessary. At no point in this entire discussion do I take the New Testament writings for granted or assume that they are some inspired set of books, or think that, by citing a text, it must therefore be true. In fact, I will employ a methodology that utilizes only those data that are acknowledged by the majority of philosophers, historians, and New Testament scholars who study this topic. Further, these facts are decidedly not true simply just because the scholars say that they are so. Rather, my argument uses these facts because the supporting data establish them as true. There is a reason why most scholars across a wide breadth of positions-atheist, agnostic, liberal, moderate, and conservative-all accept the historicity of these facts. It is because the data are so strong that they are acknowledged by these scholars as true. In other words, the New Testament writings could even be unreliable, as some of these scholars definitely think, but each of these facts would still follow (for details, see Habermas, 2003, Chapter 1).

I turn now to six major dissimilarities between the resurrection appearances of Jesus and contemporary ADC experiences such as those that Vincent cited. It is my contention that these dissimilarities can indicate the variance between these two categories of phenomena (cf. Habermas, 2008). Quite intriguingly, many of those authors who want to make some positive connection between resurrection appearances and ADCs still recognize the force of these distinctions that argue otherwise, as I will note below.

First, in a shift that began about three or four decades ago, a strong majority of researchers now accept the historicity of the empty tomb. My survey (Habermas, 2005, pp. 140-141) of scholars since 1975 lo- 
cated over 20 arguments favoring this event. These arguments include the proclamation of the event in Jerusalem, where it could have been disproven easily in the face of the Christian preaching there; that women were the original witnesses; the multiple independent sources that report this event; the early date of the reports; and that even enemy reactions conceded the empty tomb. Most scholars consider this case to be substantially stronger than the one against it.

The empty tomb would be a powerful indication that whatever occurred at the resurrection happened to Jesus' body, just as the Gospels indicate. Other rival hypotheses are, of course possible, but rarely do scholars think that any of these alternatives are viable. This point alone is a huge problem for Vincent's thesis, which tends to contrast Paul with the Gospels. But if the Gospels are correct about the empty tomb, it would seem that bodily appearances cannot be too far behind. In spite of Perry's (1959) position on ADCs, even he agrees that the evidence is sufficient to establish that the tomb was empty (pp. 101102). Vincent (2012) seemed to recognize the force of this argument, as well (p. 138).

Second, there are at least a half-dozen critical indications that Jesus predicted both his death and resurrection several times prior to their occurrences (see Mark 8:31, 9:31, 10:33-34, 14:27-28). These predictions are found in the early literature, are attested by multiple independent sources, and fulfill the recognized critical criteria of embarrassment, dissimilarity, and plausibility, plus lacking theologizing and Old Testament parallels, all of which are reasons well-recognized in the scholarly community. These reasons overpower the few reasons for doubting these predictions (Licona, 2010, especially pp. 65-66).

These repeated predictions would indicate that Jesus was well aware of both his coming death and his resurrection/exaltation, as well as something of the role they played in God's planned salvation. This foresight would further differentiate his post-crucifixion sightings from ADC cases, because Jesus would have known the nature of his fate ahead of time, including his appearing later, which most likely points to the knowledge of this specific plan (cf. Allison, 2005, p. 230).

Third, as Keim (1872) pointed out in the late 19th century, the New Testament differentiates the resurrection appearances from other visions, including those of Jesus himself (p. 595). But if the resurrection appearances were basically disembodied ADCs anyway, it does not follow that they would be separated or differentiated from the latter. Something other than ADCs must be going on here (Allison, 2005, pp. 261, 321-326). ADCs were well known in the ancient world, too, but 
were not expressed in terms of resurrections. This is one of the chief contributions of Tom Wright's (2003) major study.

Fourth, a major consideration is that, in order to get anything even remotely like the early, accredited list of resurrection appearances that is so respected by contemporary scholars (sightings by individuals and groups, including 500 at once, most likely both inside and outside, etc.), one would have to string together a lengthy combination of ADC sightings, as Vincent (2012) himself did (pp. 140-144). But no single ADC case, to my knowledge, even approaches the diversity of the resurrection appearances, which actually makes them look rather unique.

Perry (1959) made the similar point that, in terms of the sheer number of witnesses, not even the best ADC cases approach the detailed list of Jesus' resurrection appearances. If the Gospel data are also included, both the time length of the appearances and the extent of the conversations serve as additional indicators of the distinctiveness of Jesus' appearances (Perry, 1959, pp. 181-187). Allison (2005) seems to have been similarly impressed with the strength and diversity of the resurrection appearance traditions (pp. 228-269, 285).

Fifth, in addition to Paul's own comments regarding his resurrection appearance in 1 Corinthians 9:1; 15:8, recent scholars take quite seriously at least some of the elements of Luke's three accounts of Paul's conversion in Acts 9:1-9, 22:6-11, and 26:12-18 (Allison, 2005, pp. 236, 263-266; Vincent, 2012, p. 138). Whatever is to be made of Luke's descriptions, they include a few elements that seem foreign to ADC phenomena-such as an extremely bright light from heaven seen by all those persons present that caused everyone to fall to the ground. This occurrence seems unlike at least the general sort of ADC.

Sixth, for apparently the majority of scholars today, the earliest New Testament witnesses, including Paul, taught that Jesus' resurrection appearances were bodily events. For a few examples, those who take this recent view includes skeptics like Dale Allison (2005, p. 317) and even some scholars who reject supernatural events such as ADCs and the resurrection altogether, such as John Dominic Crossan (Crossan \& Reed, 2004, pp. 6-10, 296, 341-345), Gerd Lüdemann (1994, pp. 35, 177), and Bart Ehrman (2000, p. 296). In N. T. Wright's (2003) most influential study on this topic, The Resurrection of the Son of God (2003; see also Licona, 2010, especially pp. 400-437), he clearly favored this thesis. If true, this would really be a major blow to Vincent's (2012) thesis, as he seemed to recognize (p. 138). Vincent assumed that this view is not very popular in contemporary scholarship ("Paul knew 
nothing about a physical resurrection of Jesus" [p. 138]). But the view that Vincent described is an older one and has largely changed in the most current state of research (Habermas, 2005, pp. 143-144, 147).

In at least these six areas, the resurrection appearances were clearly dissimilar from at least typical ADCs, and some of the aspects above seem to differentiate the resurrection from any ADCs. As such, in spite of some similarities, I consider it best not to interpret the resurrection appearances as events in this category.

\section{Conclusion}

I do not want to lose sight of the fact that even though Vincent and I are at opposite ends of the theological spectrum, we both agree that Jesus actually rose from the dead, as well as on several other important points. For example, he holds that, whereas Jesus did not appear in a regular body, Paul and the disciples did see a "bodily form" (Vincent, personal communication, July 16, 2012). For me, as I have said, this is the most important portion of this subject, and so there is no need to even debate the facticity of this event here.

Neither do I question the reality of the best-attested ADC experiences. I have studied the data for decades and have always been impressed with the more evidential cases, as I mentioned above. This is another key point of agreement between us.

Still, my overall theme here has been that when Jesus was raised from the dead and appeared to his disciples and others, these events, in a somewhat trivial way (by definition), would in some sense comprise communications after his death. But this communication is by no means the same as identifying these appearances as ADCs similar to the well-known reports throughout the ages. This distinction is chiefly because, more generally, the logical form of the case itself cannot sustain the argument. The most that the argument can indicate is that there are similarities, not that they are the same class of events. More specifically, I find at least six important considerations that argue that Jesus' resurrection appearances were not ADCs in the normal, usual sense of these events.

\section{References}

Allison, D. C. (2005). Resurrecting Jesus: The earliest Christian interpretation and its interpreters. New York, NY: T. \& T. Clark.

Copi, I. M. (1986). Introduction to logic (7th ed.). New York, NY: Macmillan. 
Crossan, J. D., \& Reed, J. L. (2004). In search of Paul: How Jesus's apostle opposed Rome's empire with God's Kingdom: A new vision of Paul's words and world. San Francisco, CA: Harper Collins.

Ehrman, B. D. (2000). The New Testament: An historical introduction to the early Christian writings. New York, NY: Oxford University Press.

Habermas, G. R. (2003). The risen Jesus and future hope. Lanham, MD: Rowman \& Littlefield.

Habermas, G. R. (2005). Resurrection research from 1975 to the present: What are critical scholars saying? Journal for the Study of the Historical Jesus, 3(2), $135-153$.

Habermas, G. R. (2006). Experiences of the risen Jesus: The foundational historical issue in the proclamation of the resurrection. Dialog, 45(3), 288-297.

Habermas, G. R. (2008). Dale Allison's resurrection skepticism: A critique. Philosophia Christi, 10(2), 303-313.

Johnson, L. T. (1986). The writings of the New Testament: An introduction. Philadelphia, PA: Fortress.

Keim, T. (1872). Die Geschichte Jesu von Nazara: Das Jerusalemische Todesostern (Vols.1-3). Zurich, Switzerland: Orell, Füssli.

Licona, M. (2010). Did Jesus predict his death and vindication/resurrection? Journal for the Study of the Historical Jesus, 8(1), 47-66.

Licona, M. (2010). The resurrection of Jesus: A new historiographical approach. Downers Grove, IL: InterVarsity Academic.

Lüdemann, G. (1994). The resurrection of Jesus: History, experience, theology (J. Bowden, Trans). Minneapolis, MN: Fortress.

Perry, M. C. (1959). The Easter enigma: An essay on the resurrection with special reference to the data of psychical research. London, England: Faber and Faber.

Vincent, K. R. (2009). NDEs and universal salvation. Retrieved from http://www .near-death.com/experiences/origen021.html.

Vincent, K. R. (2012). The Resurrection of Jesus as an after-death communication. Journal of Near-Death Studies, 30(3), 136-147.

White, L. M. (2004). From Jesus to Christianity: How four generations of visionaries and storytellers created the New Testament and Christian faith. New York, NY: Harper Collins.

Wright, N.T. (2003). The resurrection of the Son of God. Minneapolis, MN: Fortress. 